\title{
DYNAMICS OF BRADYRHIZOBIUM JAPONICUM NUMBER ON SOYBEAN SEED
}

\author{
Gumeniuk I.I., Sherstoboeva O.V., Chabanyuk Ya.V. \\ Institute of Agroecology and Environmental Management \\ of the National Academy of Agricultural Sciences of Ukraine \\ 12, Metrologichna str., 03143, Kyiv \\ gumenyuk.ir@gmail.com
}

\begin{abstract}
The culture broth of Bradyrhizobium japonicum LG 2 and LG 5 strains of nodule bacteria were analyzed. The expediency of using pre-sowing treatment with simultaneous use of treaters Maxim, Vitavaks $200 \mathrm{FF}$ and Redigo M, which are popular today, was tested. The dynamics of the nodule bacteria $B$. japonicum abundance on the surface of soybean seeds was estimated at 12 hours of cultivation. Processing the composition of both isolated strains allowed saving $2 \cdot 10^{3} \mathrm{CFU} /$ seed. Key words: soybean, nitrogenfixing bacteria, nodule bacteria, symbiosis Bradyrhizobium japonicum.
\end{abstract}

Динаміка чисельності Bradyrhizobium japonicum на насінні сої. Гуменюк І.І., Шерстобосва О.В., Чабанюк Я.В. У статті проаналізовано культуральні рідини штамів бульбочкових бактерій Bradyrhizobium japonicum LG 2 та LG 5. Перевірено доцільність застосування передпосівної обробки з одночасним застосуванням популярних сьогодні протруйників: Максим, Вітавакс 200 ФФ і Редіго М. Оцінено динаміку чисельності бульбочкових бактерій $B$. japonicum на поверхні насіння сої за умови обробки культуральними рідинами виділених штамів бульбочкових бактерій сої В. japonicum LG 2 та LG 5. Oбробка композицією обох виділених штамів дала змогу збереження $2 \cdot 10^{3} \mathrm{KУО/насінину.} \mathrm{Ключові} \mathrm{слова:} \mathrm{соя,} \mathrm{азотфіксувальні} \mathrm{бактерії,}$ бульбочкові бактерії, симбіоз, Bradyrhizobium japonicum.

Динамика численности Bradyrhizobium japonicum на семенах сои. Гуменюк И.И., Шерстобоева Е.В., Чабанюк Я.В. В статье проанализированы культуральные жидкости штаммов клубеньковых бактерий Bradyrhizobium japonicum LG 2 и LG 5. Проверена целесообразность применения предпосевной обработки с одновременным применением популярных на сегодняшний день протравителей Максим, Витавакс 200 ФФ и Редиго М. Оценена динамика численности клубеньковых бактерий B. japonicum на поверхности семян сои на протижении 12 часов культивирования. Обработка композицией обоих выделенных штаммов позволяла сохранить $2 \cdot 10^{3} \mathrm{KOЕ/семя.} \mathrm{Ключевые} \mathrm{слова:} \mathrm{соя,} \mathrm{азотфирующие} \mathrm{бактерии,} \mathrm{клубеньковые} \mathrm{бактерии,} \mathrm{сим-}$ биоз, Bradyrhizobium japonicum.

Introduction. Biological nitrogen is needed to produce environmentally friendly crop products. Thanks to biological nitrogen $\left(\mathrm{N}_{2}\right)$, which is fixed in symbiosis with nodule bacteria, it has become real to obtain significant organic yields. Nearly $40 \%$ of leguminous crops seeds in Ukraine are treated with preparations of nodule bacteria, and the number of national biological preparations is $10 \%$. Very important is the shelf life of the preparation based on living nodule bacteria, which, with complete sterility, continue to grow and function. Their growth and multiplication stop only when they reach a certain concentration in the liquid, lack of nutrients and ageing of the bacteria population. Also there is an accumulation of metabolites and toxins, which can in further use reduce the symbiotic properties of bacteria.

Therefore, it is interesting to create and study bacterial preparations with a long shelf life, which remain activity and stay on the surface of seeds. Modern inoculants increase the rate of symbiosis formation, activate the nitrogenase complex of the bacteria and also contribute increasing plant resistance to adverse environmental conditions. In addition, the preparations contain unique components that contribute to an increase in the adhesive ability of bacteria to be fixed on the surface of seeds and ensure their storage for at least two months.

Literary review. As distinct to the inoculum on a dry carrier, the liquid carrier allows the manufacturer to include a sufficient amount of nutrients, protective agents to improve the characteristics of bacterial cells. In fact, they are microbial cultures or suspensions, supplemented with substances that improve adhesion, contribute stabilization, increase the ability of surfactants [1]. Although the shelf life of conventional inoculants based on solid carriers is about 6 months, another advantage of liquid preparations is that their shelf life can reach 2 years [2]. They have gained popularity in developed countries for the treatment of legumes due to the large titer of microorganisms ( 2 billion cells $/ \mathrm{ml}$ ), which 
makes possible to reduce the rate of inoculum application [3]. In addition, it is argued that these inoculants are not contaminated, have a longer shelf life of the components of the nutrient medium, are more protected from environmental stresses and could increase efficiency in the field compared with peat-based inoculants $[1 ; 4]$. They are easier to use - contribute to even application and keeping on the surface of the seed. The main component of the medium is sucrose or mannose. Glycerin contributes to the preservation of microbial preparations for 6 months (content of significant amount of water allow to protect bacteria from drying). In most cases, high molecular weight polymeric materials are added, such as carboxymethyl cellulose, gum arabic and polyvinylpyrrolidone (PVP). Exactly PVP contributes to the survival of Bradyrhizobium japonicum [1]. With the arabian gum, PVP provides some protection against drying and additional protection against exudates of inhibitory seed shells that are harmful for rhizobia. Thus, liquid inoculants occupy the main niche in the market and their advantages and disadvantages need to be studied and developed.

The aim of the research was to establish the effectiveness of the use of culture fluids of nodule bacteria as the basis of biological preparations with modern protectors and to determine the dynamics of the number of soybean nodule bacteria Bradyrhizobium japonicum on the surface of soybean seeds.

Materials and methods. The experiments were conducted in the laboratory of ecology of microorganisms of the Institute of Agroecology and Nature Management of the NAAS. It was used Moravia soybean, which was grown in the Forest-Steppe of Ukraine and included to the "Register of Plant Varieties of Ukraine" from year 2011.

The objects of research were selected breeds of soybean nodule bacteria and their culture broth of strains Bradyrhizobium japonicum LG 2 and LG 5. The working titer of the preparations was $5-6 \cdot 10^{9} \mathrm{CFU} / \mathrm{ml}$.

The dynamics of the number of nitrogen-fixing microorganisms on the seeds was determined as follows:
$10 \mathrm{~g}$ of inoculated soybean seeds were placed in $100 \mathrm{ml}$ of water at certain intervals of storage time and shaken at $220 \mathrm{vol} / \mathrm{min}$. Within 30 minutes a series of 10 -fold dilutions of the cell suspension was prepared and sown on mannitol yeast agar (MYA). From each flask, a $0.1 \mathrm{ml}$ suspension was taken separately with a sterile pipette and applied to the agar surface and with a Drygalsky sterile spatula, holding the half-open cup near the burner flame, and gently rubbed into the agar plate. The plates were placed in a thermostat for 10 days at a temperature of $26-28^{\circ} \mathrm{C}$. The titer of bacterial cells in the water wash was $1-8$ thousand $/ \mathrm{ml}[5]$.

The determination of the titer of the obtained soybean nodule bacterial strains was carried out by sowing $10^{6}$ dilutions of the suspension of culture broth on MYA. The presence and amount of extraneous microflora was determined by sowing $10 \%$ suspension of culture broth in sterile tap water on Meat extract-peptone medium to detect extraneous bacteria and the presence of micromycetes on Chapek's medium.

Inoculants and culture broth of nodule bacteria Bradyrhizobium japonicum LG 2 and LG 5 were used for presowing treatment of the studied seed samples in combination with the most common seed treatment preparations: Maxim, Vitavaks $200 \mathrm{FF}$, Redigo M, which have protective fungicidal and regulatory properties. Determined the number of colonies forming units (CFU) after storage for 30 and 60 days.

Results of the research and discussion. We determined the dynamics of the titer of viable cells of soybean nodule bacteria of strains Bradyrhizobium japonicum LG 2 and LG 5 on the surface of soybean seeds under monosteam inoculation and combined use of the composition of two strains LG 2 and LG 5. In both of the variants of Bradyrhizobium japonicum inoculation pressure was $8.27 \cdot 10^{3}$ cells per 1 seed. The control served as seeds treated with water and the titer of epiphytic rhizobia per 1 seed did not exceed 100 cells.

In the study of washed out of inoculated soy seeds, which were obtained by shaking in sterile

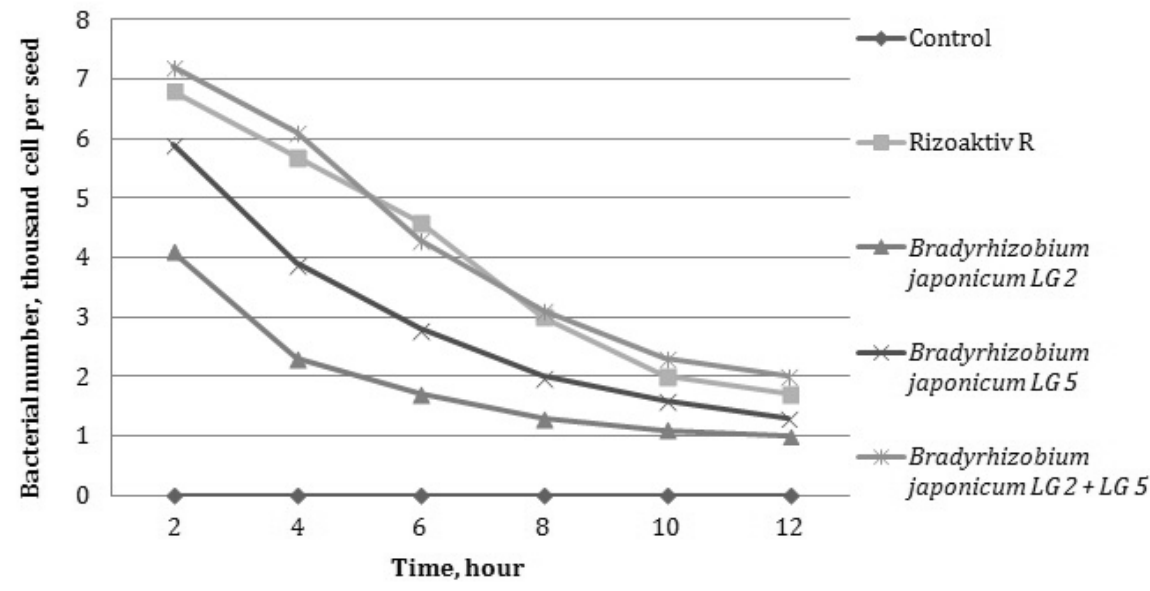

Fig. 1. Dynamics of Bradyrhizobium japonicum numder per seed of soybean 
water for 30 minutes in a shaker at 220 vol per minute, it was shown that in the first 2 hours the number of Bradyrhizobium japonicum decreases in all variants of the experiment. In particular, in the variant with the LG 2 strain, the number was $4.110^{3}$ cells / seed, in variant with the strain LG $5-5.9 \cdot 10^{3}$ cells/seed, and when inoculated with the composition of both strains of nodule bacteria soybeans - up to $7.2 \cdot 10^{3}$ cells/ seed, which is by $5.7 \%$ more compared to the national modern inoculant Rizoaktiv R (Fig. 1).

As the control in these studies we used seeds treated with water and the epiphytic titer of rhizobia existing on 1 seed did not exceed 100 cells. To compare the effectiveness of our existence, we used a modern innovative biological product for treating soybean Rizoaktiv R.

Within 12 hours, the titer of B. japonicum strain during its inoculation decreased in all variants of the experiment. In particular, in the variant with usage strain LG 2, the number of nodule bacteria was $1.0 \cdot 10^{3}$ cells / seed, in the variant with strain LG 5 in monoinoculation - up to $1.3 \cdot 10^{3}$ cells / seed. In another case, when inoculated with the composition of both strains of soybean nodule bacteria, the rhizobia titer decreased only to $2.0 \cdot 10^{3}$ viable cells per 1 seed, which is $15 \%$ more than the modern national inoculants Rizoaktiv R. The similar results have already been obtained and described by Spanish researchers where seeds of legumes were inoculated with including soybean, they differed only in absolute numbers while maintaining the general trend [6]. The delay in reducing the titer of nodule nitrogen-fixing bacteria on soybean seeds when inoculated in the complex of two strains is done, we consider several of the following features, namely, the presence of viscous exopolysaccharides that synthesize strain LG 5 and which in turn protect against the effects of factors damaging bacterial cells, and also helps to keep cells on the surface of seeds, recent studies of these strains have been shown [7].

After conducting research to determine the dynamics of the number of nodule bacteria on the surface of soybean seeds, it will be important to evaluate the culture fluids for a certain period of suitability for further biological development based on them. Therefore, we tested the vital activity of nitrogen-fixing bacteria in the culture broth. For microorganisms, a liquid nutrient medium is not only a source of nutrition and functioning, it also play the protection role against negative environmen- tal factors during storage of the preparations, as well as exposure to the soil. One of the main advantages of the liquid form of inoculants is the high efficiency compared to the dry, due to the combination of several microorganisms, as well as the possibility of $100 \%$ covering of soybean seeds due to the liquid carrier. The effect of the use of biological preparations based on living microorganisms may differ depending on certain criteria, such as the characteristics of bacteria, the method of their application, as well as various environmental factors, infused on them in the process of life activity (biotic, abiotic, anthropogenic). Any of these factors will have an effect on the inoculum, which can provide an inhibitory effect or will lead to increasing the amount of biological agent in the preparation or outdoor microflora in it. One of the important factor in the successful introduction of microorganisms into biogeocenosis is the properties of these microorganisms, their relationship with plants and already existing microorganisms of this biogeocenosis.

The results of determining the dynamics of the bacteria titer during storage of culture broth are the basis of the possible preparation and their own quality indicators during the corresponding storage period are shown (Table 1).

Mature 1-2 day old cultures of strains Bradyrhizobium japonicum LG 2 and LG 5 had a titer of 5-6 billion cells per $1 \mathrm{ml}$ [8]. A rapid fall in cell titer in the first half of the month and a slight increase in its further storage up to 2 months may indicate that the strains of Bradyrhizobium japonicum LG 2 and LG 5 restore the population in the nutrient substrate.

During storage of culture broth for a certain period of the presented options, no contamination from micromycetes was observed, and contamination by extraneous bacteria was 2-3 times lower than allowed by the standard at the end of the storage period [9]. Despite the change in the titer of bacterial cells in the culture broth of both strains of nodule bacteria after 3 months of storage, as well as more than 1.5 billion/g of viable cells up to 6 months is sufficient (for technical requirements) to inoculate seeds per 1 ha.

From the literature it is known that the introduction of large amounts of inoculum into the substrate leads to a rapid loss of titer, which is not updated, because metabolites of bacteria from the suspension interfere with this. Conversely, the introduction of a small amount of inoc-

Table 1

The quality of the culture broth of the nodule bacteria Bradyrhizobium japonicum

\begin{tabular}{|c|c|c|c|c|c|c|c|c|}
\hline \multicolumn{2}{|c|}{ Strain } & \multicolumn{7}{c|}{ Storage terms, months } \\
\cline { 3 - 8 } & $\mathbf{0 . 5}$ & $\mathbf{1}$ & $\mathbf{2}$ & $\mathbf{3}$ & $\mathbf{4}$ & $\mathbf{5}$ & $\mathbf{6}$ \\
\hline \multicolumn{2}{|c|}{ Bradyrhizobium japonicum LG 2, billion/ml } & 3.4 & 3.5 & 3.7 & 3.2 & 2.5 & 2.1 & 1.7 \\
\hline \multirow{2}{*}{ Outdoor microflora, \% } & extraneous bacrteria & 0 & 0 & 0.1 & 0.2 & 0.2 & 0.4 & 0.4 \\
\cline { 2 - 9 } & micromycetes & 0 & 0 & 0 & 0 & 0 & 0 & 0 \\
\hline \multicolumn{2}{|c|}{ Bradyrhizobium japonicum LG 5, billion/ml } & 4.2 & 4.4 & 4.6 & 3.5 & 3.2 & 2.4 & 2.1 \\
\hline \multirow{2}{*}{ Outdoor microflora, \%o } & extraneous bacrteria & 0 & 0 & 0.1 & 0.2 & 0.2 & 0.2 & 0.3 \\
\cline { 2 - 9 } & micromycetes & 0 & 0 & 0 & 0 & 0 & 0 & 0 \\
\hline
\end{tabular}


The number of viable microorganisms on soybean seeds when processing the culture broth of nodule bacteria in combination with various treaters

\begin{tabular}{|c|c|c|c|c|}
\hline \multicolumn{3}{|c|}{ Variant } & $\begin{array}{c}\text { Bradyrhizobium japonicum } \\
\text { thousand CFU ( } 30 \text { days) }\end{array}$ & $\begin{array}{c}\text { Bradyrhizobium japonicum } \\
\text { thousand CFU ( } 60 \text { days) }\end{array}$ \\
\hline 1 & \multirow{3}{*}{ Rizoaktiv R } & Treater Maxim & $3.91 \pm 0.2$ & $3.12 \pm 0.2$ \\
\hline 2 & & Treater Vitavaks $200 \mathrm{FF}$ & $3.45 \pm 0.2$ & $2.95 \pm 0.2$ \\
\hline 3 & & Treater Redigo M & $2.31 \pm 0.2$ & $1.92 \pm 0.2$ \\
\hline 4 & \multirow{3}{*}{ Strain LG 2} & Treater Maxim & $3.71 \pm 0.2$ & $2.02 \pm 0.1$ \\
\hline 5 & & Treater Vitavaks $200 \mathrm{FF}$ & $3.23 \pm 0.1$ & $0.96 \pm 0.1$ \\
\hline 6 & & Treater Redigo M & $1.06 \pm 0.1$ & $0.92 \pm 0.2$ \\
\hline 7 & \multirow{3}{*}{ Strain LG 5} & Treater Maxim & $3.15 \pm 0.5$ & $3.06 \pm 0.2$ \\
\hline 8 & & Treater Vitavaks $200 \mathrm{FF}$ & $7.16 \pm 0.3$ & $4.68 \pm 0.2$ \\
\hline 9 & & Treater Redigo M & $2.45 \pm 0.2$ & $2.14 \pm 0.1$ \\
\hline 10 & \multirow{3}{*}{$\begin{array}{l}\text { Strain (LG } 2 \\
\quad+\text { LG 5) }\end{array}$} & Treater Maxim & $2.91 \pm 0.5$ & $3.21 \pm 0.5$ \\
\hline 11 & & Treater Vitavaks $200 \mathrm{FF}$ & $3.69 \pm 0.2$ & $0.83 \pm 0.3$ \\
\hline 12 & & Treater Redigo M & $4.21 \pm 0.2$ & $3.21 \pm 0.5$ \\
\hline
\end{tabular}

ulum with a low titer of cells (biological inoculation) contributes to the adaptation of bacteria to the substrate, which form a new population of the strain [10].

Soybean seeds, which were treated with the most commonly used treaters for today (Maxim, Vitawax 200 FF, Redigo M) and inoculated of culture brothof the nodule bacteria strains selected by us in previous studies [11]. Seed treatment is a complex action aimed at destroying the infection of plant or bacterial origin and suppressing infections in the soil and creating a danger to plants, reducing their density and crops, suppressing their growth and development in general. This allows for treatment to protect against diseases and pests in combination with soybean inoculation, which reduces the chemical load on crops and reduces the number of treatments [12].

Among the variants presented in our research, we can say that when applying culture broth of strains of Bradyrhizobium japonicum LG 2 and LG 5 and protectant Vitavaks $200 \mathrm{FF}$, which has a fungicidal effect and acts as a growth regulator, the number of viable nodule bacteria of all the experience options was $3.23 \cdot 10^{3}$ CFU and $7.16 \cdot 10^{3} \mathrm{CFU}$, and in the composition of both strains $-3.69 \cdot 10^{3} \mathrm{CFU}$ (Table 2).

In the variants with the use of the mentioned strains and the treater Maxim, which has fungicidal properties, the following place was noted in terms of the number of viable nitrogen-fixing bacteria grown on solid MDA $3.15-3.71 \cdot 10^{3} \mathrm{CFU}$ among the variants presented in the studies and $-2.91 \cdot 10^{3} \mathrm{CFU}$ in the composition of both strains.

The lowest in the number of nodule bacteria was characterized by the variants with the use of culture broth Bradyrhizobium japonicum LG 2 and LG 5 and the treater of Redigo M. The number of CFU there was 1.06-2.45 $\cdot 10^{3} \mathrm{CFU}$, and when applying the composition of culture broth (LG $2+$ LG 5) $-4.21 \cdot 10^{3}$ CFU.

Thus, we can conclude that after 30 days from the moment of seed treatment with drugs (inoculum and dis- infectants), a large number of nitrogen-fixing microorganisms are still on the surface of the seeds.

A month later, a similar microbiological seeding of the experimental variants presented in the studies was carried out, that is, in just 60 days. A similar trend was observed in the number of nitrogen-fixing microorganisms of the genus Bradyrhizobium japonicum on the surface of soybean seeds after washing in an aqueous solution. Inoculation increases the storage period of microorganisms on the surface of soybean seeds, where every hour it is extremely important to characterize the practicality of using the drug based on these strains of bacteria. For comparison, the table shows the dynamics of the number of modern soybean inoculum Rizoaktiv R.

Thus, when using culture fluids in a composition with modern disinfectants, it is possible to preserve the quality of seeds, to provide protection against diseases along with the subsequent increase in nitrogen-fixing activity of symbiotic systems, which will be formed due to soybean nodule bacteria. The use of high-quality inoculants with a high content of nitrogen-fixing bacteria for the treatment of seeds of leguminous crops is today a necessary practice, which will ensure good yields for a better return on investment.

Conclusions. Consequently, the presence of viscous exopolysaccharides that synthesize the tuber bacterial strains Bradyrhizobium japonicum LG 2 and LG 5 protects against the effects of factors damaging bacterial cells, as well as contributes to cell retention on the surface of the seed. Based on the conducted research, the effectiveness of the preparation of culture broth of the strains of nitrogen-fixing soybean nodule bacteria Bradyrhizobium japonicum LG 2 and LG 5 for the treatment of soybean seeds using modern disinfectants Maxim, Vitavaks 200 FF, Redigo M with protective fungicidal and regulatory properties for the survival of bacteria of the genus Bradyrhizobium japonicum was established. 


\section{References}

1. Herridge D. Inoculants and Nitrogen Fixation of Legumes in Vietnam. Brisbane: PK Editorial Services, $2002.116 \mathrm{p}$.

2. Stephens J.H.G., Rask H.M. Inoculant production and formulation. Field Crops Research. 2000. Vol. 65. Issue 2/3. P. $249-258$.

3. Schulz T.J., Thelen K.D. Soybean seed inoculant and fungicidal seed treatment effects on soybean. 2008. Crop Science. Vol. 48. P. $1975-1980$.

4. Date R.A. Advances in inoculant technology: a brief review. Australian Journal of Experimental Agriculture. 2001. Vol. 41. Issue 3. P. 321-325.

5. Alternatives to peat as a carrier for rhizobia inoculant: solid and liquid formulations / M. Albareda, D. Rodriguez-Navarro, M. Camacho, F. Temprano. Soil Biol Biochem. 2008. Vol. 40. P. 2771-2779.

6. Synthesis of exopolisaccharides by Bradyrhizobium japonicum isolates / I.I. Gumeniuk, S.Yu. Gruzinskii, I.S. Brovko, Ya.V. Chabanyuk. Ekolohichni nauky. 2018. № 22. P. 153-156.

7. Hotjanovich A.V. Metody kultivirovanija azotfiksirujushhih bakterij, sposoby poluchenija i primenenija preparatov na ih osnove: Methods for cultivating nitrogen-fixing bacteria, methods for preparing and using preparations based on them. Leningrad, $1991.60 \mathrm{p}$.

8. TCC 319.00494456-006. 2002. Preparat bulbochkovych bakterii pid bobovi kultury - Ryzobofit [Preparation of nodule bacteria for legumes - Rizobofit].

9. Biopreparaty azotfiksirujushhih bakterij: problemy i perspektivy primenenija / E.V. Sherstoboeva, I.A. Dudinova, S.N. Kramarenko, N.K. Sherstoboev. Micriobilogy journal. 1997. № 4. P. 109-116.

10. Screening of aboriginal Bradyrhizobium bacteria from soil and their symbiotic properties / I.I. Gumeniuk, S.Yu. Gruzinskii, I.S. Brovko, Ya.V. Chabanyuk. Agroecological journal. № 3. P. 77-81.

11. Ekolohichna ocinka vplyvu pestycydiv ta agrochimikativ na gruntovi mikroorganizmy: metodychni rekomendaciii / Ya.V. Chabanyuk, O.V. Sherstoboeva, V.V. Chaikovska, A.M. Klymenko, V.U. Yashchuk, A.P. Korecky, G.O. Iutynska. Kyiv, 2015. 63 p.

12. Catroux G, Hartmann A, Revellin C. Trends in rhizobial inoculant production and use. Plant Soil. 2001. № 230. P. 21-30. 